\title{
ORGANIZATIONAL AND MANAGERIAL RESOURCE-METHODOLOGICAL POSSIBILIITIES FOR COMPETITIVENESS GUARANTEEING
}

\section{ОРГАНИЗАЦИОННО-УПРАВЛЕНЧЕСКИЕ РЕСУРСНО-МЕТОДОЛОГИЧЕСКИЕ ВОЗМОЖНОСТИ ОБЕСПЕЧЕНИЯ КОНКУРЕНТОСПОСОБНОСТИ}

\section{Shedyakov Vladimir ${ }^{1}$}

DOI: dx.doi.org/10.30525/978-9934-571-30-5_25

Abstract. The scientific-theoretical and methodological basis of the text is the elaborations of specificities, firstly, the cycles of socio-economic transformations of cultural-civilizational worlds; secondly, post-modern inter-paradigm competition, thirdly the opportunities and limits of organizational and managerial impact on competitiveness. The presentation of the findings of the study takes place within the framework of the development from the 80 's years of XX century author's analytic-synthetic concept of the epochal cycle with reference to the features of interparadigmality. In particular, the purpose of the article is to characterize the new organizational and managerial accents that allow increasing competitiveness in social transformations of the paradigmatic level, enhancing the personal and public sounding of the scientific and intellectual potential.

From the author's point of view, the way out of inter-paradigm crises accentuates the possibilities of a general civilian polylogue in the formation of "sobornost" and harmonization of interests when a new social consensus is reached. Organizational and managerial design requires a plastic account of the entire range of resource-methodological transformations. Strengthening the features of the "smart society" accentuates the importance of the scientific and intellectual potential of society in the development of technical and technological basis of new industrial structures. Attempts to emphasize transit and tourism or natural economy are doomed to long-term political and economic dependence and lack of autonomy.

\footnotetext{
${ }^{1}$ Doctor of Sociological Sciences, Candidate of Economic Sciences, Free-lance, Ukraine 
In turn, the course to develop the potential of the "smart society" ceases to be a declaration only with a real priority of the points of development (primarily in the form of scientific and educational-production clusters), and developing socio-economic environment (in particular, mass training in creativity in labour and management). The structures of the oligarchy, which subordinates the political and economic tendencies of private (clan, group, family) self-seeking and egoistic goals become a significant obstacle to cardinal democratization and humanizing the relations of labour, property and management.

\section{1. Вступление}

Культурно-цивилизационные миры проходят фазы метаморфоз отнюдь не синхронно, участвуя во взаимодействиях на разных этапах своих изменений. Каждый из культурно-цивилизационных миров осуществляет социетальные трансформации, включающие как циклично повторяемые, так и невозвратно-уникальные (как поступательно-прогрессивные, так и регрессивные) движения. Взаимодействия между культурно-цивилизационными мирами, имеющие черты партнёрства / кооперации и конкуренции / состязания, приобретают черты большей / меньшей комплиментарности и / или антагонизма.

Отношения партнёрства и конкуренции, пути усиления / ослабления позиций соревнующихся сторон изучены на основе работ, прежде всего, В. Миллара, М. Портера, Дж. Робинсон, Ф. Хайек, Э. Чемберлина, а также Г. Азоева, Е. Александровой, Л. Байрачной, 3. Борисенко, Л. Вальраса, И. Гончаровой, И. Гуркова, С. Емельянова, Дж. Кейнса, Г. Куликова, А. Маршалла, Ю. Осипова, А. Пигу, П. Сраффы, Р. Фатхутдинова, А. Шмелёва, А. Юданова. Возможности управления в этом контексте рассмотрены с учётом анализа И. Ансоффа, А. Арсеенко, А. Богданова, А. Венделина, Г. Гантта, А. Гастева, Д. Гвишиани, В. Глушкова, В. Голикова, П. Друкера, Г. Жебита, П. Керженцева, Ф. Кожурина, Э. Короткова, В. Косолапова, А. Костусева, А. Кредисова, П. Лебедева, Д. Макгрегора, А. Мелентьева, Р. Оуэна, Г. Попова, И. Поповой, А. Пригожина, А. Румянцева, Г. Слезингера, Е. Старосьцяка, Л. Суворова, Ф. Тейлора, Ю. Тихомирова, Ж. Тощенко, Дж. Траута, А. Тюрго, А. и М. Уилсонов, Б. Украинцева, Г. Форда, Г. Хакена, Ф. Херцберга, А. Чандлера, А. Чухно. Изложение выводов исследования происходит в рамках разрабатываемой с 80-х гг. ХХ в. авторской 


\section{Chapter 12. Economic sciences}

аналитико-синтетической концепции эпохального цикла применительно к особенностям межпарадигмальности.

Для каждого этапа цикла развития характерно своё сочетание возможностей и опасностей, влияние которых существенно усиливается / ослабевает соответственно управленческим выборам элиты и характеру общественной среды данного культурно-цивилизационного мира. При этом решения принимаются, зачастую, с приоритетом либо собственных эгоистических (персональных, семейно-клановых), либо всего своего культурно-цивилизационного мира интересов. В межпарадигмальный переходный период организационно-управленческие возможности способны оказать определяющее влияние на характер отношений и место каждого из культурно-цивилизационных миров в складывающейся структуре ойкумены. Соответственно, роль качества управленческих композиций, проявляемого в корреляции стратегии, тактики и оператики действий, возрастает при межпарадигмальном переходе, в частности, форсированных постиндустриальных, постглобальных и, в целом, постсовременных преобразованиях.

В этом контексте целью данной статьи является характеристика новых организационно-управленческих акцентов, позволяющих обеспечить повышение конкурентоспособность при общественных трансформациях парадигмального уровня, усиливающих личностное и общественное звучание научно-интеллектуального потенциала.

\section{2. Конкурентно-состязательное поле жизнедеятельности}

Конкурентно-состязательное поле свойственно человеческой жизнедеятельности [1-5]. Вместе с тем, ничем не ограниченная конкуренция граничит с неупорядоченной «войной всех со всеми» и чревата последующим монопольным диктатом. Чистая частная собственность, совершенная конкуренция, рыночное ценообразование в нынешних условиях - аналитические абстракции, преодолённые общественным развитием. Ныне его общественная среда кардинально меняется; человечество входит в период гораздо более радикальных перемен, нежели привычные. И дело отнюдь не в смене одной стадии (формации, этапа и т.п.) другой. Существо трансформаций связано с перерастанием стадиального (формационного, этапного) развития, с преодолением материальной доминанты жизнедеятельности. Бифуркация такого уровня привела когда-то к порождению самого общественно-биологического 
развития. Происходит сложное движение, которое совмещает в себе совершенно разные модели, сценарии и процессы, порождая высокую специфичность возможностей и рисков.

Радикальный характер и размах трансформаций очевидны. Ныне осуществляются изменения не только отдельных социальных институтов, но и самих моделей жизнедеятельности и развития, культурной среды, отношений и структур. Переход к постсовременной логике свободы является, одновременно, отказом от единства любого базиса жизнедеятельности и развития. Всё активнее заявляет о себе процесс изменений, предусматривающих сосуществование, перекрещивание и взаиморезонирование самых разнообразных тенденций развития, среди которых (в отличие от модели развития модерна или традиции) ни одна не может претендовать на то исключительное значение, которое позволило бы без вреда для конечного результата абстрагироваться от прочих. Т.о. речь идёт уже отнюдь не только о политических условиях реализации свободы, но и о значительно более глобальных её перспективах, связанных с доминантой терпимости и многоукладности. В этой ситуации стремительно увеличиваются гетерогенность, неопределённость, взаимопроникновение разных фрагментов, подвижность границ, кардинально меняется соотношение общественных норм и аномалий. Когда нет стабильной внешней опоры в виде общей идеологии, единственной культуры, стереотипной науки, тогда необходимо признавать право на существование и конкурирование непохожего, особенного и необычного [6-9]. Новый диапазон социальных ролей каждого усиливает влияние культуры на восприятие полифункциональности в процессе жизнедеятельности. Преодоление же «внеморальной» модели принятия решений, рост антропоцентрических тенденций радикально обогащает творческий потенциал: человек умеет и знает больше, чем осознаёт. Модели трансформаций, опирающиеся на «экономию на переменном капитале» и педантичное описание функций и действий закономерно теряют истинность при усилении тенденций становления постглобального «умного общества».

При этом полиструктура мирохозяйственных связей как целостность, основанная на выработанных и взаимоприемлемых нормативах отношений, а вовсе не блок из идентичных атомов-элементов, приобретает вид формирующейся действительности. Межпарадигмальная конкуренция между культурно-цивилизационными мирами втя- 
гивает в себя все виды международных отношений, подчиняя своим задачам как собственно экономические, так и внеэкономические ресурсы и получая существенные отличия при постсоциалистическом и постсовременном дрейфе [10-13]. Причём в условиях «стабильной нестабильности» парадигмальных практических и теоретических изменений приходится поддерживать конкурентоспособность как доживающими, так и рождающимися ресурсно-методологическими возможностями. В частности, особое значение в условиях как эволюционного накопления преимуществ, так и (особенно) кардинальных перемен приобретают базовые для культурно-цивилизационных миров ценностно-смысловые комплексы, формирующие традиции, социальный капитал, еtс. Наличие мощных ценностно-смысловых комплексов - обязательное условие мощного культурно-цивилизационным мира, его хозяйственной подсистемы. Осуществление продуктивной настройки всего хозяйственного механизма предполагает повышения внимания к сформированным социокультурным традициям, развитию вокруг них и на их основе культурно-цивилизационных миров. Органичное развитие общества при этом связано с доминированием в его социокультурном капитале черт интеграции, а не разобщённости; на основании согласования, а не подчинения интересов общественных групп. Результат участия в конкуренции при этом часто предопределяются самодисциплиной, готовностью работать на своём месте с предельной самоотдачей, на грани и за гранью возможного, а также командной слаженностью, согласованностью, когерентностью. Динамизм и направленность формообразования зависит от качества исторической череды Сверхпроектов, которые могут заметно изменяться, перенимая черты своих новых носителей. Соответственно, для мобилизации ресурсно-методологических баз всё более важным становится формирование Сверхпроекта развития, открывающего простор для созидательных возможностей и обеспечивающего вовлечённость и мотивирование каждого. А проступающие в масштабах «большого общества» признаки постсовременности смещают акценты в создании и пере/распределении общественного богатства, а, соответственно, и роль факторов и методологии преобразований. Соответственно, в зависимости от точки ценообразования (в частности, потребительских благ) в различных общественных укладах существенно смещаются и возможности каждой из общественных групп. 


\section{3. Конкурентно-состязательные возможности постсовременности:} роль развития и реализации научно-интеллектуального потенциала

Знание - важнейшее измерение общества и экономики постсовременности. Нарастание структурирующего значения экономики знаний акцентирует роль центров по их выработке, аккумулированию и использованию, одной из эффективных организационных форм которых выступают научно-образовательно-производственные комплексы. И характер новой парадигмы социально-экономической жизнедеятельности, и особенности переходного периода требуют приоритетности в культивировании точек развития общества. Поддержка научно-образовательно-производственных комплексов как кластеров развития и направления повышения конкурентоспособности с ядром из мозговых центров - необходимость обеспечения коренных интересов культурно-цивилизационного мира в обществе знаний. Развитие и реализация как научно-интеллектуального потенциала, так и материально-технической базы является необходимым условием обеспечения политической самостоятельности и экономического суверенитета в условиях глобального перехода к обществу знаний [11-17]. В свою очередь, интенсивная диффузия навыков и умений из хозяйственной сферы в прочие делает научно-образовательно-производственные кластеры фактором не просто инновационного поиска, а преобразования общества как целостности. Ядром научно-образовательно-производственных кластеров как базы стабильного развития социума становятся аналитические центры и научно-образовательные комплексы, в формировании которых эффективно взаимодействуют общество, государство и бизнес. Вместе с тем, обладание информацией и знаниями само по себе - необходимая, но не достаточная предпосылка комплексного органичного развития экономики и общества. Например, накопленный в СССР огромный: человеческий и аналитический - потенциал не помог не только освоить информационную модель роста, но и сохранить государство. При этом в последние годы существования Советского Союза создание обширного научно-технического потенциала и материально-технической базы отнюдь не завершилось столь же значительными подвижками в социально-экономической и духовно-нравственной сферах. За последнюю же четверть века на постсоветском пространстве как дальнейшая деградация материально-технической базы, так и отток кадров стали направлениями утраты экономической 
самостоятельности. Например, долгосрочные интересы народа при принятии решений порой подменяются выполнением рекомендация институций международного неоимпериализма (того же МВФ или Мирового банка) либо интересов олигархических групп. Между тем, освоение горизонтов развития - функция не соответствия формальным штампам и занесённым информационными вирусами прокрустовым ложам стандартов, а результат повышения качества жизни и возможностей творчества.

Качественно-количественное усложнение ойкумены под воздействием процессов постсовременных, постглобальных и постиндустриальных трансформаций требует адекватного изменения потенциала эффективного практико-теоретического влияния на действительность. Так, кардинально расширяются объективные основания для повышения многоуровневого разнообразия. Усиливает общественное звучание формула «творческая многоликость - жизнь, единообразие - уродование в прокрустовом ложе и смерть». Живое противоречиво, через разрешение противоречий осуществляется развитие. Отсутствие противоречий - признак остановки и смерти, упрощение - путь деградации. При этом безудержный оптимизм и потоки безбрежной «чернухи» в равной степени могут инспирироваться для отсечения исторических альтернатив и направления к «единственно верному пути» (например, с использованием принципа окна Овертона). Напротив, высвобождение созидательного потенциала (а не звериных инстинктов) требует осознанности своей жизнедеятельности и рефлексивности мышления. Между тем, иное возможно, однако требует духовной, душевно-нравственной и интеллектуальной работы, суть которой концентрируется вокруг творчества. При этом перед каждым стоит выбор приоритета: выживание / благополучие собственное (в частности, с присоединением к ценностно-смысловым комплексам господствующего в данный момент культурно-цивилизационного мира) - или же своего культурно-цивилизационного мира. Соответственно, при разнообразии путей социогенеза борьба за возрождение ценностно-смысловых комплексов своего культурно-цивилизационного мира прямо и непосредственно оказывается в числе высших приоритетов социума. Так же, как и ресурсы её воплощения: культура, идеология, наука. И, особенно, образование, сущность которого - не культуртрегерство или натаскивание обрывков знаний, а именно образование личности, её созидание 
(самосозидание). Так, духовные трансформации и интеллектоёмкое творчество - условие выживания и развития ойкумены как разнообразия культурно-цивилизационных миров. Знание - условие понимания при интерпретации: процессы освоения (в частности, распредмечивания) требуют восприятия репрезентованного смысла.

В свою очередь, научно-образовательный комплекс сегодня - неотьемлемая часть как успешного научно-образовательно-промышленного цикла, так и механизма социально-экономического развития. С одной стороны, научно-образовательный комплекс обязан предоставлять качественные услуги по своему профилю, воспитывая (именно образовывая, формируя) человека не только как носителя товара рабочая сила, но и как личность, готовую к встрече с задачами информационной эры, вызовами (пост)современного уровня. С другой, - для этого необходимо опираться на широкое привлечение заинтересованных в результатах подготовки представителей различных слоев гражданского общества (в первую очередь, работодателей). Соответственно, на фоне кардинальности постглобализационных трансформаций на макроэкономическом уровне процессы конкуренции и партнёрства, в тенденциях микроэкономики повышение значения факторов стимулирования использования одарённости работника выносят на первый план обеспечения своей конкурентоспособности интеллектуальность схем хозяйствования. Вместе с тем, именно ухудшение не только состояния экономики, но и динамики её изменений сопряжено с ухудшением качества инвестиционной направленности, например, акцентированием вложений в морально устаревшие циклы, предприятия низкого технологического уклада и т.п., что повышает зависимость экономики от внешних процессов, обескровливает и ослабляет хозяйственный потенциал культурно-цивилизационного мира. Напротив, обеспечение приоритетности научно-образовательно-производственных кластеров в состоянии не только дать толчок развитию экономики, но и способствовать росту независимости и субъектности на мировой арене. При этом как развитие производственной демократии / народовластия, так и кардинальное усложнение материально-технической базы воспроизводства, в свою очередь, требуют содержательного и функционального изменения социального пространства экономики, всей общественной среды ойкумены. В условиях же инверсионного развития (если не гражданское общество создаёт государство, а государство обеспечи- 
вает функционирование гражданского общества) развитая и структурированная общественность предполагает достижение определённого экономического уровня. Предиктором же в точке бифуркации может оказаться и слабое воздействие в ключевой точке.

\section{4. Организационно-управленческие возможности конкурентно- состязательного развития и реализации творческого потенциала}

Человек как социальное животное требует организационно-управленческой фиксации существования и развития. Соответственно, организационно-управленческие отношения являются условием жизни и реализации каждого, фактором устойчивого социально-экономического развития. Конкурентно-состязательное поле человеческой жизнедеятельности корреспондируется с характером взаимоотношений культурно-цивилизационных миров, находящихся в состоянии разного движения и на различных фазах своих циклов, соответственно - обладающих спецификой сильных и слабых конкурентных сторон, преимуществ и недостатков, учёт и использование которых становится одной из важнейших задач совершенствования организационно-управленческих отношений. Важность спонтанности для творчества и индивидуализм комбинаций одарённости не отрицают организационно-управленческого оформления, однако, резко усложняют его.

Совокупность регуляторных методов включает как прямые (директивного управления), так и косвенные (стимулирующие, вызывающие заинтересованность). Направленность регуляторных методов существенно зависит от представлений об эпохе, фазе цикла хозяйственной конъюнктуры, возможностях и ограничениях антикризисного регулирования [18-21]. Их существенная часть проистекает из особенностей информационной эры, сопряжённой с повышением значения экономики знаний и деятельности когнитариата. Какие-то ресурсно-методологические зоны закрылись, будучи исчерпанными, иные перестали быть определяющими. Это резко ограничивает продуктивность попыток воспроизвести мировой опыт прошлых модернизаций, воспользоваться калькой со своих прежних инноваций: иное время, другие факторы и составляющие успеха.

Эффективная форма удержания организационно-управленческой структуры, обеспечивающей продуктивный вектор социально-экономической общности - Сверхпроект развития культурно-цивилизаци- 
онных миров. При этом необходимость нового Сверхпроекта развития накладывается сегодня на нерешённость задач и классического модерна, сосуществование хозяйственных укладов, базирующихся на культуре традиционной, модерной и постмодерной, обществе аграрном, индустриальном и постиндустриальном, включающем канву и логику азиатского способа производства, настоянного на всеобщей частной собственности, что влечёт применение понятий постнедомодерна или квазипостмодерна и широкое регулятивное использование ряда иррационально-превращённых форм. Смысл истории и «сравнительные» итоги жизнедеятельности каждого из культурно-цивилизационных миров гораздо глубже, нежели простой баланс эгоистических интересов и рациональное столкновение сил. В ней (в том числе в её экономической составляющей) осуществляется нравственное содержание, формируемое тысячелетиями взаимодействия и кооперации. За использование же отрицательной моральной силы для реализации своего Сверхпроекта, за насилие над моралью и человечностью всегда следует расплата. И возмездие обязательно, хоть воздается не всегда виновному, чаще история «бьёт по площадям». При учёте же лишь наиболее очевидных регуляторно-управленческих связей и механизмов (например, монетарных) из виду упускается широчайший спектр реакций общества как социально-политической и социокультурной целостности. Вместе с тем, сегодня форсированная трансформация инверсионно включает в себя «в снятом виде» элементы классической вестернизации, однако же, отнюдь не сводится к ним.

Ныне для успешного достижения целей новой модернизации необходимо и оправданно привлекать ресурсные базы как модернизации (домодернизации недомодерна), так и постмодернизации. При этом, разумеется, чем выше общественное положение члена команды, тем жёстче требования к нему. Соответствующим образом, и постсовременное видение государства всеобщего благосостояния предполагает не скопление разнообразных социальных иждивенцев и их обслуги, а активную поддержку творчества (прежде всего, интеллектуального и духовного) с реализацией приоритета человека, его прав и свобод; социальной справедливости, то есть социального равенства людей в правах и возможностях; солидарности, понимаемой как выражение общности человечества и сочувствия к жертвам несправедливости. Другими словами, общее процветание сегодня связывается, скорее, с 
ценностно-смысловыми комплексами отнюдь не праздности и потребительства, а созидания и творческого поиска. Таким же образом на базе ведущих ценностно-смысловых комплексов культурно-цивилизационных миров корректируются и формы обеспечения продуктивного социального согласия. Соответственно, из понимания задач рождается расстановка приоритетов в оптимизации средств, предпочтительных направлениях науки, образования, промышленности, трансформации комплекса регуляторной политики, методологии и ресурсов ценообразования.

Соответственно, дополнительные вложения в человека - это вовсе не обременительная социальная нагрузка, а непременное условие качественного участия в конкурентной борьбе на верхних этажах экономики, где место экономии на переменном капитале в качестве магистрального направления получения стратегического выигрыша занимает творческий интеллектоёмкий труд, требующий тщательной подготовки и обеспечения, в том числе, путем стимулирования и управления. Между тем, механическое имитирование творчества не приносит искомого результата. Международные же тенденции распространения принципов и механизмов экономики знаний распространяются в глобализованном мире, вызывая в жизнь не только миграционные процессы, но и ориентации в подборе работы на внешние фирмы (в том числе и без изменений страны жительства). Тем самым квалифицированная рабочая сила тяготеет к конкурентоспособным условиям самораскрытия, развития и жизнедеятельности, а постсовременная глобализация информационного пространства открывает для этого новые возможности и ниши.

Таким образом, для обеспечения прогрессивных структурных изменений необходимо заботиться о качестве стратегического, тактического и оперативного дизайна страны, базирующихся совсем не на шароварщине далекого прошлого, не на буколическом воспевании сельской идиллии, а на атрибутике XXI века - научно-образовательных кластерах, требующих регуляторного подтверждения соответствующего уровня мотивирования персонала. Для этого необходимо опираться на широкое привлечение заинтересованных в результатах их профессионально-образовательной подготовки представителей различных слоёв общества. Соответственно, на передний план выходят задачи налаживания эффективных контактов с «большим обще- 
ством» по вовлечению в реализацию этих подходов для реализации постсовременного Сверхпроекта жизнеустройства и развития своего культурно-цивилизационного мира.

Роль качества управленческих композиций, проявляемого в корреляции стратегии, тактики и оператики действий, возрастает при межпарадигмальном переходе, в частности, форсированных постиндустриальных, постглобальных и, в целом, постсовременных преобразованиях [22-27]. Стратегический дизайн данного межпарадигмального перехода акцентирует интеллектуальную составляющую жизнедеятельности. Переход к постсовременным ресурсно-методологическим базам и моделям стратегического дизайна экономики общества знания, усиление роли анклавов «умного общества», «информационный взрыв» воздействуют на соотношение возможностей и факторов осуществления, реактивизируя как творческие (прежде всего, научно-интеллектуальные) возможности культурно-цивилизационных миров, так и устойчивость их базовых ценностно-смысловых комплексов, а также умение ими распорядиться, их защитить, активизировать и нарастить, в частности - посредством социокультурных полей. Впрочем, при сдвигах парадигмального уровня трансформируются и характер общежития, и структура переходного периода. Одновременно уже и само человечество превратилось в фактор, соизмеримый с мощью всей Природы. В то же время результаты участия в конкуренции часто обусловлены как индивидуальной самодисциплиной, готовностью работать с предельной самоотдачей, на грани и за гранью возможного, так и командными взаимодействием, согласованностью, когерентностью, что прямо связано с организационно-управленческими решениями в стратегическом дизайне общества. Таким образом, с одной стороны, определяются новые рубежи социализации / аккультурации и индивидуализации, с другой же, - отнюдь не какие-либо формальные конструкты, а качество жизни и возможности творчества предопределяют прогресс страны, новые же горизонты развития открываются тем государствам, в которых общественное устройство максимально способствует реализации творческого потенциала населения, а Сверхпроект мобилизует на решение созидательных задач.

Вместе с тем, постсоветские преобразования, накладываясь на особенности постиндустриализма, постглобальности и, в целом, постсовременности, порождают модификации социокультурной и полити- 
ко-экономической среды реформ. В это время как программирование будущих социально-экономических процессов, так и управление тенденциями нынешней хозяйственной жизни ресурсами общественного стратегического дизайна коррелирует с особенностями постсовременности как среды моделей и практик формирования чернового наброска будущего, создания его замысла и выявления намерения, наиболее обострённо проявляясь в форсированных трансформациях переходного периода к структурированию экономикой, основанной на знаниях.

Главным фактором успеха при реализации организационно-управленческих технологий прорывного уровня становятся гибкость, мобильность, восприимчивость, умение быстро адаптироваться к изменениям хозяйственной конъюнктуры, возможности чего концентрируются в управленческих композициях, представляющих собой комплексные инновационные решения по освоению эффективных организационно-управленческих моделей в данных конкретных условиях. Как известно, традиционная культура аграрного общества реализовывала основную функцию управления хозяйственной деятельностью в рамках формулы «делай так, потому что так делалось до тебя». В индустриальном обществе с культурой модерна генерализирующим направлением хозяйственного управления было «делай так, потому что это рационально». Для постиндустриального региона характерен подход «делай так, потому что это эффективно». Причем эффективными для региональных хозяйственных систем могут быть самые разные парадигмы осуществления управленческих композиций. Вместе с тем, под влиянием многоаспектных тенденций постмодернизации, бессмысленным является покорное следование какому-либо внешнему канону, необходим комплекс решений, позволяющих объединить логики посткризисные и развития применительно к конкретным условиям. Заведомая ресурсно-методологическая плюральность постсовременности (от постмодерной культуры до постиндустриальных отношений, включая духовное производство) предполагает преодоление обязательности канонов и штампов, проявление и реализацию подлинной свободы выбора для каждого и базируется, скорее, на развитии своих преимуществ, а не устранении отличий, подчас воспринимаемых как недостатки. Соответственно, нужно осовременивание, модернизация, - но она отнюдь не обречена следовать модели вестер- 
низации, тем более - в «догоняющих» вариациях. Притом из каждого класса моделей (традиционных, модерных, постмодерных) жизнеустройства и развития конкретный культурно-цивилизационный мир может получить свою конкретику соответственно как своим ценностно-смысловых комплексам, так и динамике трансформации.

В этих условиях и само понятие развития нуждается в обновлении: кроме стабильного и сбалансированного роста, оно должно обеспечивать инновационными формами традиционно выработанные механизмы общественного бытия и ориентироваться на такие максимы как солидарность, свобода выбора, убеждений и слова, терпимость, востребуя адекватной гибкости управления (flexible management), прежде всего, - ресурсами стимулирования. Так, в частности, создание объективных условий для наращивания потребности в творческом труде и реализации высокоиндивидуальной одарённости сотрудника требует кардинальных сдвигов, связанных с переходом от методов директивного управления к стимулированию деятельности, широкому задействованию ценностно-смысловых комплексов персонала, применению арсенала производственной демократии, социального партнёрства, гибких форм организации и регулирования. Соответственно, требуется и изменение хозяйственной культуры, и обновление арсенала эффективного управления. Дискредитация технократических рецептов менеджмента как нереалистичных, усиление внимания к ценностным ориентациям продемонстрировали, что традиционные организационные подходы не соответствуют современной экономической и технологической структуре общества. Именно поэтому неоконсервативные традиционные ценностные ориентации зачастую обновляются под знаком усиления мотивов социальной ответственности, умеренности, самоограничения, закрепление состояния социальной иерархии. Социал-демократы необходимость обновления ценностных ориентаций обусловливают так же, как и неоконсерваторы, исчерпанность традиционного понимания технического прогресса, социальной политики «государства благоденствия», экологическим кризисом и т.д. Однако, выход из этой ситуации сторонники демократического социализма видят скорее в создании условий ценностно-правового порядка, способствующих формированию зрелой личности, которая самостоятельно проявляла бы свою волю и принимала активное участие в реализации позитивного содержания определяющих ценностей на основе 


\section{Chapter 12. Economic sciences}

толерантного консенсуса. У неоконсерваторов поиск ценностных ориентаций осуществляется через апелляцию к традициям как воплощению выверенного историей опыта, а также к народным обычаям, в которых закрепляется «позитивный» и отклоняется «негативный» смысл. Вследствие такой направленности реактуализируется интерес к базовой культуре, прежде всего к ценностно-смысловым комплексам. Причем большинство теоретиков-неоклассиков в области управления подчёркивает, что в условиях глобальной информатизации значение имеет не столько мощь управленческого воздействия на систему как целостную, сколько векторно-целевое влияние на отдельную необходимую точку системы. Инновационно-синергетический подход в управлении естественно согласовывается с чертами объекта управления и элементами системы принятия решений, т.е. вся сложность управления нелинейными системами содержится в анализе пространственно-временных параметров проблем, что позволяет принимать нестандартные решения, осуществляя точечные изменения с позиций системного видения желаемого. В сфере высоких технологий наукоёмких отраслей это особенно существенно. Опора на опыт «ручного управления» закрепляет отставание управленческих решений и, тем более, действий - от социальных процессов, а вера в оптимальность стихийного развития ослабляет регулятивные возможности общества, тогда как опережающее отражение сложной реальности наукой закладывает базу для адекватности управленческих механизмов мировым тенденциям развития. На институционально-структурном уровне соответствующее реформирование корпораций усиливает тенденции к ликвидации нагромождения управленческих звеньев, превращению ранее занятых в контрольно-распределительных функциях в советников по повышению профессиональности решений, в площади же ценностно-культурной вместо традиционного культа лояльности, сервильности и исполнительности ориентирует на чувство собственного достоинства, достижения профессионализма, свободы и творчества. Одновременно идет переход от директивного администрирования к стимулированию желательных изменений (в том числе, в поведении) как модели управленческого воздействия.

В переходные времена целесообразно инвестировать в наиболее перспективных специалистов. Соответственно, особое значение для прогрессивных подвижек в социальном капитале приобретают про- 
цессы формирования групп людей (от менеджеров до высококвалифицированных специалистов, техников и рабочих), работающих с помощью знаний (что получает научное обоснование в различных концепциях т.н. когнитариата, нового интеллектуального класса, knowledge workers и т.д.), что не только способно трансформировать базу развития как экономики, так и всего общества, но и ставит новые задачи в сфере мотивации. Для успешного же проведения очередной модернизации и эффективного использования механизмов стимулирования желательных трансформаций при сетевой организации постглобального общества, необходимо культивировать механизмы не «обязывать», «заставлять», «администрировать», а «увлекать», «заинтересовывать», «мотивировать». Другими словами, обеспечение управляемости общественными процессами требует акцентирования технологий стимулирования желательных изменений как форм управления. Причём сегодня благодаря своему диапазону последствий использование стимулирующих механизмов социального партнёрства, обогащения деятельности, производственной демократии, групповой организации труда, гибкого рабочего времени, корпоративной культуры, проектно-матричного управления и создания на их основе управленческих композиций в состоянии дать комплексный инновационно-синергетический кумулятивный эффект социетального уровня, обеспечивая управляемость как индивидуальным поведением, так и общественными процессами. Вместе с тем, с одной стороны, содержание социально-экономической деятельности, выходя за пределы формального контроля, усиливает акцент на «патисипативности» в своей организации, на ответственном взаимодействия с кругом заинтересованных участников (стейкхолдеров) - и, соответственно, распространённая сегодня модель корпорации ориентирована именно на вариант компании участников (stakeholder's company), воздействия на уровне сущностных сил, прежде всего - интересов и ценностей. С другой стороны, успех интеллектуальной деятельности часто напрямую требует многообразия профессиональных и общекультурных коммуникаций, ещё теснее интегрирует в кооперативные связи, производственные и социальные сети, что не толь способствует дальнейшему нарастанию социального капитала, но и трансформирует его структуру.

При этом в принимаемых решениях необходимо отражать задачи как собственно переходного периода, так и долговременных форми- 
рующихся динамик, обеспечивая место в высококонкурентной среде. Между тем, сегодня во многих влиятельных государствах к власти идёт поколение «пост-бэби-бумеров», с представителями которого и будут конкурировать лидеры Украины. Новое же поколение государственных управленцев в мире, как правило, существенно отличается от предшественников. В этой ситуации крайне угрожающим для страны становится отставание генераций её лидеров от времени, сохранение стереотипов, иллюзий и подходов прежних эпох. Как известно, смена элит связана не столько с возрастными изменениями, сколько со сдвигами мировоззренческими, этапами в диалоге общества и государства, населения и власти. Так что проблема качества элиты общество не решается только надеждами на новое поколение. В постсоветском пространстве появилась генерация «богатых детей» с идеологией потребительства, легких обогащения и жизни. Они имеют много, но это - не их достижения. Существенная часть детей нынешних олигархов и бюрократов не только оторвана от жизни страны и широких масс её граждан, но и не способна самостоятельно принимать ответственное участие в реальной общественной жизни.

Проблемность обеспечения общественных безопасности и развития связана с тем, что именно они должны противостоят лидерам других стран в отстаивании национальных интересов. И эта необходимость учёта глобального аспекта трансформаций дополнительно акцентирует значение преобразований системообразующих отношений труда, собственности и управления. При этом обеспечение кардинальной демократизации сферы собственности, естественно связанное с повышением взаимозависимости и кооперации, усиливает противостояние интересов олигархата и народа как целого, социального структурирования с антагонизмом приоритета целей олигархов либо общества знания. Так, радикальное расширение круга участников принятия общественно важных решений, преодоление деления на преимущественно управляющих и исполняющих становится неотьемлемым элементом и подъёма народного творчества (в частности, в труде и управлении), и развития субъектности трансформаций, и улучшения позиций во взаимодействии между культурно-цивилизационными мирами в период межпарадигмального перехода. Жёсткая (само)дисциплина, (само)организация и (само)ограничение, как и ассоциирование топ-менеджерами себя с народом, а также развёрну- 
тые многоуровневые социально-политические коммуникации и предельная социальная ответственность элиты - обязательные условия качественного социетального управления.

Субъектность трансформаций международных экономических отношений сказывается на их долговременных и краткосрочных результатах. Для своей активизации потенциал созидателей как главной производительной силы и движителя «рефлексивной постмодернизации» требует опоры как на пласты знания, развитый интеллект, так и на духовно-нравственные факторы. Причём в момент сдвигов парадигмального уровня, при приближении к состоянию институциональной неопределённости, приходится не столько руководствоваться привычными регуляторными правилами, сколько ориентироваться, с одной стороны, на ценностно-смысловые комплексы своего культурно-цивилизационного мира (которые, реализуясь в формах традиций, обычаев, укладов и обеспечивают воспроизводство и развитие экономики и общества в целом), с другой же, - на общую логику исторического процесса и свои конкретные особенности.

Между тем, соотношение возможностей и рисков, горизонтов и границ осуществления стратегии, тактики и оператики преобразований подвижно. А эффективными могут быть самые разные парадигмы осуществления управленческих композиций. Впрочем, при сдвигах парадигмального уровня трансформируются и характер общежития, и структура переходного периода. Это время усиливает искушение субстратных народов изменением своих ценностей, названий и смыслов соответственно главенствующим штампам, а государств-лимитрофов - реализацией чужих (чуждых) им подходов. Оптимизация же стратегии дальнейшего развития, коррекция внешнего и внутреннего курса следуют, прежде всего, из представлений об отечественном выборе своих моделей хозяйствования и конкурентоспособной в мире жёсткой «гиперконкуренции» ресурсно-методологических баз, ниш и подходов специализации. Соответствующим образом в диапазоне желательного и возможного должны меняться как стратегия, так и тактика / оператика управления общественными явлениями, отношениями и процессами. Так, обеспечение качества жизни и условий творчества выходит на передний план управления, соответствующим образом трансформируя актуальные ресурсно-методологические базы и перенацеливая их на рост диапазона применения глубоко 
индивидуального сочетания сущностных сил каждого, в частности, благодаря механизмам социального партнёрства и производственной демократии.

\section{5. Выводы}

Общество-естественная среда формирования человека. При этом социализация/аккультурация становятся неотъемлемой составляющей индивидуализации. Таким образом, развитие и раскрытие сугубо индивидуальной комбинации одарённости каждого - задача дальнейшего организационно-управленческого совершенствования культурно-цивилизационного мира.

Выход из межпарадигмальной кризисности акцентирует возможности общегражданского полилога в формировании соборности и гармонизации интересов при достижении нового общественного консенсуса. Организационно-управленческий дизайн требует пластичного учёта всего диапазона ресурсно-методологических трансформаций.

Усиление черт «умного общества» акцентирует значение научно-интеллектуального потенциала общества в освоении технико-технологических узлов новых индустриальных укладов. Постиндустриальные, постглобальные и, в целом, постсовременные процессы делают контрпродуктивными попытки воспроизводства неоархаики. Евроатлантический вектор интеграции слабо коррелирует с сельскохозяйственной антиутопией натурально-хуторянского типа в условиях массового избыточного производства той же сельскохозяйственной продукции в странах ЕС. Попытки акцентировать транзитность или туризм обрекают на длительную политико-экономическую зависимость и несамостоятельность.

В свою очередь, курс на освоение потенциала «умного общества» перестаёт быть пустой декларацией лишь с реальной приоритетностью как точек развития (прежде всего, в форме научно-образовательно-производственных кластеров), так и обеспечения развивающей социально-экономической среды (в частности, массовым обучением творчеству в труде и управлении).

Существенной помехой кардинальным демократизации и очеловечиванию отношений труда, собственности и управления становятся структуры олигархата, подчиняющего политико-экономические 
тенденции реализации частных (клановых, групповых, семейных) корыстно-эгоистических целей и задач.

Дальнейшее научное осмысление темы, по нашему мнению, может быть оптимизировано путём перемещения фокуса анализа на изменение характера эффективных организационно-управленческих воздействия и комплекса мер стимулирования разной длительности последствий.

\section{Список литературы:}

1. Хайек Ф.А. Конкуренция как процедура открытия / Ф.А. Хайек // Мировая экономика и международные отношения. - 1989. - № 12. - С. 7-13.

2. Азоев Г.Л. Конкуренция: анализ, стратегия и практика / Г.Л. Азоев. М. : Центр экономики и маркетинга, 1996. - 208 с.

3. Шмелёв А.Г. Продуктивная конкуренция. Опыт конструирования объединительной концепции / А.Г. Шмелёв. - М. : Магистр, 1997. - 56 с.

4. Юданов А.Ю. Конкуренция: теория и практика / А.Ю. Юданов. 2-е изд. - М. : Гном-Пресс, 1998. - 384 с.

5. Фатхутдинов Р.А. Стратегическая конкурентоспособность / Р.А. Фатхутдинов. - М. : Экономика, 2005. - 504 с.

6. Джохадзе И.Д. Демократия после модерна / Игорь Джохадзе. - М. : Праксис, 2006. -112 с.

7. Шедяков В.Е. Постглобализм как социально-экономическое явление / B.Е. Шедяков // Рyxes. - 2016. - № 4 (3). - С. 104-114.

8. Шедяков В.С. Досягнення й утримання конкурентоспроможності в умовах посилення ролі економіки знань / В.С. Шедяков // Формування ринкових відносин в Україні. - 2015. - № 4 (167). - С. 22-29.

9. Шедяков В.Е. Гармонизация индивидуального и социального в становлении общества знания / В.Е. Шедяков // European vector of contemporary psychology, pedagogy and social sciences: the experience of Ukraine and the Republic of Poland / Ed. board: M. Kiedrowska, A. Erechemla, T. Branecki. Sandomierz, Poland : Baltija Publishing, 2018. - Vol. 3. - P. 446-470.

10. Федотова В. Модернизация «другой» Европы / В. Федотова. - М. : ИФ РАН, 1997. - $255 \mathrm{c}$.

11. Шедяков В.Е. Переходность как характеристика состояния постсоветского пространства / В.Е. Шедяков // Economy and Society: a Modern Vectors of Development: Proceedings of II International Scientific Conference. - Leipzig, Germany, April 27th, 2018. - Part II. - P. 92-94.

12. Шедяков В.Е. Между умным обществом и диктатурой крупного капитала/ В.Е. Шедяков // Суспільні науки: напрямки та тенденції розвитку в Україні та світі: Матер. Міжнар. наук.-практ. конф. - Одеса, 2016. - С. 71-75.

13. Шедяков В.Е. Творчество или потребительство, новый Сверхпроект или утрата исторической субъектности? / В.Е. Шедяков // Творчество как способ бытия свободы: Материалы XII Международной научно-практ. конф. Киев, 2013. - С. 210-212. 
14. Доброва Т.Г. Відтворення індустріального потенціалу - стратегічне завдання економічної політики України / Т.Г. Доброва // Стратегічні орієнтири розвитку економіки України: Матер. Міжнар.наук.-практ. конф. - Одеса, 6-7 жовтня 2017. - С. 24-27.

15. Ніколаєв Ю.О. Формування регіональної промислової політики, як імператив модернізації економіки України: теорія, методологія, практика / Ю.О. Ніколаєв. - Одеса : Друкарський дім, 2011. - 316 с.

16. Шедяков В.Е. Научно-образовательно-производственные кластеры точки развития экономики и общества / В.Е. Шедяков // Innovative Economy: Processes, Strategies, Technologies: Proceedings of the II International Scientific Conference. - Kielce, Republic of Poland, January 26 ${ }^{\text {th }}$, 2018. - Part I. - P. 65-67.

17. Шедяков В.С. Посилення духовно-інтелектуальної спрямованості трансформацій - умова виживання та розвитку людства / В.С. Шедяков // The Formation of a Modern Competitive Environment: Integration and Globalization: Proceedings of the International Scientific Conference. - Greenwich, UK, May $25^{\text {th }}$, 2018. - Part I. - P. 45-47.

18. Перкинс Д. Исповедь экономического убийцы / Д. Перкинс. - М. : Pretext, 2005. -319 c.

19. Газенко Р. Идеальный шторм. Технология разрушения / Р. Газенко, А. Мартынов. - М. : Книжный мир, 2016. - 272 с.

20. Шедяков В.С. Організаційно-управлінські відносини як стратегічний ресурс розвитку / В. Є. Шедяков // Формування ринкових відносин в Україні. 2016. - № 3 (178). - C. 23-30.

21. Шедяков В.С. Стратегічний організаційно-управлінський дизайн соціально-економічних точок розвитку суспільства / В.С. Шедяков // Економіст. 2015. - № 12. - C. 13-18.

22. Дагаев А.А. Новые модели экономического прогресса с эндогенным технологическим прогрессом / А.А. Дагаев // Мировая экономика и международные отношения. - 2001. - № 6. - С. 40-51.

23. Суслов В. Украина в ожидании «большой сделки» / Виктор Суслов, Елена Вавилова // 2000. - № 27-28 (826). - 2017. - 7-13 июля.

24. Голян В. Экономика Украины в 2014-2017 годах: кризис управления / Василий Голян // Економіст. - 2017. - № 5. - С. 7-12.

25. Шедяков В.Е. Эффективное управление сквозь призму создания умной экономики / В.Е. Шедяков // Вісник Одеського національного ун-ту. - Сер. Економіка. - 2016. - Т. 21. - Вип. 7/49. - Ч. 2. - С. 18-22.

26. Шедяков В.Е. Стратегическое управление как фактор постглобальной конкуренции / В.Е. Шедяков // The global competitive environment: development of modern social and economic systems: Proceedings of the International Scientific Conference. - Chisinau, Republic of Moldova, April 21st, 2017. - P. 53-55.

27. Шедяков В.Е. Возможности и риски эпохи: научно-исследовательская рефлексия - рефлексивное управление - рефлексивная модернизация / В.Е. Шедяков // Management of modern socio-economic systems / ed. by J. Žukovskis, K. Shaposhnykov; Aleksandras Stulginskis University, Business and Rural Development Management Institute. - Kaunas, Lithuania : Baltija Publishing, 2017. - Vol. 1. - P. 201-218. 


\section{Shedyakov Vladimir}

\section{References:}

1. Khayek F.A. (1989). Konkurentsiya kak protsedura otkrytiya. Mirovaya ekonomika i mezhdunarodnye otnosheniya, 12: 7-13.

2. Azoev G.L. (1996). Konkurentsiya: analiz, strategiya i praktika. M.: Tsentr ekonomiki i marketinga, $208 \mathrm{~s}$.

3. Shmelev A.G. (1997). Produktivnaya konkurentsiya. Opyt konstruirovaniya ob“edinitel'noy kontseptsii. M.: Magistr, $56 \mathrm{~s}$. $384 \mathrm{~s}$.

4. Yudanov A.Yu. (1998). Konkurentsiya: teoriya i praktika M.: Gnom-Press,

5. Fatkhutdinov R.A. (2005). Strategicheskaya konkurentosposobnosit'. M. Ekonomika, $504 \mathrm{~s}$.

6. Dzhokhadze I.D. (2006). Demokratiya posle moderna. M.: Praksis, $112 \mathrm{~s}$.

7. Shedyakov V.E. (2016). Postglobalizm kak sotsial'no-ekonomicheskoe yavlenie. Pyxes, 4 (3): 104-114.

8.Shedyakov V.E.(2015).Dosyagnennyayutrimannyakonkurentospromozhnosti $\mathrm{v}$ umovakh posilennya roli ekonomiki znan'. Formuvannya rinkovikh vidnosin $\mathrm{v}$ Ukraini, 4 (167): 22-29.

9. Shedyakov V.E. (2018). Garmonizatsiya individual'nogo i sotsial'nogo v stanovlenii obshchestva znaniya. European vector of contemporary psychology, pedagogy and social sciences: the experience of Ukraine and the Republic of Poland / Ed. board: M. Kiedrowska, A. Erechemla, T. Branecki. Sandomierz, Poland: Baltija Publishing, Vol. 3: 446-470.

10. Fedotova V. (1997). Modernizatsiya "drugoy” Evropy. M.: IF RAN, 255 s.

11. Shedyakov V.E. (2018). Perekhodnost' kak kharakteristika sostoyaniya postsovetskogo prostranstva. Economy and Society: a Modern Vectors of Development: Proceedings of the II International Scientific Conference. Leipzig University, Faculty of Economics and Management Science. Leipzig, Germany. Part II: 92-94.

12. Shedyakov V.E. (2016). Mezhdu umnym obshchestvom i diktaturoy krupnogo kapitala. Suspil'ni nauki: napryamki ta tendentsiï rozvitku v Ukraini ta sviti: Mater. Mizhnar. nauk.-prakt. konf. Odesa : 71-75.

13. Shedyakov V.E. (2013). Tvorchestvo ili potrebitel'stvo, novyy Sverkhproekt ili utrata istoricheskoy subektnosti? Tvorchestvo kak sposob bytiya svobody: Materialy XII Mezhdunarodnoy nauchno-prakt. konf. Kiev : 210-212.

14. Dobrova T.G. (2017). Vidtvorennya industrial'nogo potentsialu-strategichne zavdannya ekonomichnoi politiki Ukraini Strategichni orientiri rozvitku ekonomiki Ukraini: Mater. Mizhnar.nauk.-prakt. konf. Odesa : 24-27.

15. Nikolayev Yu.O. (2011). Formuvannya regionalnoi promislovoi politiki, yak imperativ modernizatsii ekonomiki Ukrainy: teoriya, metodologiya, praktika. Odesa : Drukars'kiy dim, $316 \mathrm{~s}$.

16. Shedyakov V.E. (2018). Nauchno-obrazovatel'no-proizvodstvennye klastery tochki razvitiya ekonomiki i obshchestva. Innovative Economy: Processes, Strategies, Technologies: Proceedings of the II International Scientific Conference. - State University of Jan Kochanowski, Departament for Entrepreneurship and Innovation. Kielce, Republic of Poland, Part I: 65-67. 
17. Shedyakov V.E. (2018). Posilennya dukhovno-intelektual'noi spryamovanosti transformatsiy - umova vizhivannya ta rozvitku lyudstva. The Formation of a Modern Competitive Environment: Integration and Globalization: Proceedings of the International Scientific Conference. University of Greenwich. Greenwich, UK. Part I: 45-47.

18. Perkins D. (2005). Ispoved' ekonomicheskogo ubiytsy. M.: Pretext, 319 s.

19. Gazenko R., \& Martynov A. (2016). Ideal'nyy shtorm. Tekhnologiya razrusheniya. M.: Knizhnyy mir, 272 s.

20. Shedyakov V.E. (2016). Organizatsiyno-upravlins'ki vidnosini yak strategichniy resurs rozvitku. Formuvannya rinkovikh vidnosin v Ukraini, 3 (178): 23-30.

21. Shedyakov V.E. (2015). Strategichniy organizatsiyno-upravlins'kiy dizayn sotsial'no-ekonomichnikh tochok rozvitku suspil'stva. Ekonomist, 12: 13-18.

22. Dagaev A.A. (2001). Novye modeli ekonomicheskogo progressa s endogennym tekhnologicheskim progressom. Mirovaya ekonomika i mezhdunarodnye otnosheniya, 6: 40-51.

23. Suslov V. (2017). Ukraina v ozhidanii “bol'shoy sdelki”. 2000, 27-28 (826).

24. Golyan V. (2017). Ekonomika Ukrainy v 2014-2017 godakh: krizis upravleniya. Ekonomist, 5: 7-12.

25. Shedyakov V.E. (2016). Effektivnoe upravlenie skvoz' prizmu sozdaniya umnoy ekonomiki. Visnik Odes'kogo natsional'nogo un-tu. Ser. Ekonomika, T. 21, Vyp. 7/49, Ch. 2: 18-22.

26. Shedyakov V.E. (2017). Strategicheskoe upravlenie kak faktor postglobal'noy konkurentsii. The global competitive environment: development of modern social and economic systems: Proceedings of the International Scientific Conference. Moldova state university, Faculty of economic sciences. Chisinau, Republic of Moldova: 53-55.

27. Shedyakov V.E. (2017). Vozmozhnosti i riski epokhi: nauchnoissledovatel'skaya refleksiya - refleksivnoe upravlenie - refleksivnaya modernizatsiya. Management of modern socio-economic systems / ed. by J. Žukovskis, K. Shaposhnykov; Aleksandras Stulginskis University, Business and Rural Development Management Institute. Kaunas, Lithuania: Baltija Publishing, Vol. 1: 201-218. 